\title{
Adiabatic Fixed-Bed Gasification of Colombian Coffee Husk Using Air-Steam Blends for Partial Oxidation
}

\author{
Javier Bonilla ${ }^{1}$ and Gerardo Gordillo ${ }^{2}$ \\ ${ }^{1}$ Mechanical Engineering Department, Universidad ECCI, Cra 19 No. 49-20, Bogotá, Colombia \\ ${ }^{2}$ Mechanical Engineering Department, Universidad de los Andes, Cra 1 Este No. 19A-40, Office ML 652, Bogotá, Colombia
}

Correspondence should be addressed to Javier Bonilla; jbonillap@ecci.edu.co

Received 9 February 2017; Revised 21 June 2017; Accepted 19 July 2017; Published 13 September 2017

Academic Editor: Constantine D. Rakopoulos

Copyright (c) 2017 Javier Bonilla and Gerardo Gordillo. This is an open access article distributed under the Creative Commons Attribution License, which permits unrestricted use, distribution, and reproduction in any medium, provided the original work is properly cited.

\begin{abstract}
The increasing energy consumption, mostly supplied by fossil fuels, has motivated the research and development of alternative fuel technologies to decrease the humanity's dependence on fossil fuels, which leads to pollution of natural sources. Small-scale biomass gasification, using air-steam blends for partial oxidation, is a good alternative since biomass is a neutral carbon feedstock for sustainable energy generation. This research presents results obtained from an experimental study on coffee husk $(\mathrm{CH})$ gasification, using air-steam blends for partial oxidation in a $10 \mathrm{~kW}$ fixed-bed gasifier. Parametric studies on equivalence ratio (ER) $(1.53<\mathrm{ER}<$ $6.11)$ and steam-fuel $(\mathrm{SF})$ ratio $(0.23<\mathrm{SF}<0.89)$ were carried out. The results show that increasing both $\mathrm{SF}$ and ER results in a syngas rich in $\mathrm{CH}_{4}$ and $\mathrm{H}_{2}$ but poor in $\mathrm{CO}$. Also, decreased SF and ER decrease the peak temperature $\left(T_{\text {peak }}\right)$ at the gasifier combustion zone. The syngas high heating value (HHV) ranged from $3112 \mathrm{~kJ} / \mathrm{SATPm}^{3}$ to $5085 \mathrm{~kJ} / \mathrm{SATPm}^{3}$ and its maximum value was obtained at $\mathrm{SF}=0.87$ and $\mathrm{ER}=4.09$. The dry basis molar concentrations of the species, produced under those operating conditions $(1.53<$ $\mathrm{ER}<6.11$ and $0.23<\mathrm{SF}<0.89$ ), were between 1.12 and $4.1 \%$ for $\mathrm{CH}_{4}$, between 7.77 and $13.49 \%$ for $\mathrm{CO}$, and between 7.54 and $19.07 \%$ for $\mathrm{H}_{2}$. Other species were in trace amount.
\end{abstract}

\section{Introduction}

The actual growth in energy consumption, supplied mostly by fossil fuels that produce greenhouse and pollutant gases $\left(\mathrm{NO}_{x}, \mathrm{SO}_{x}\right)$ through combustion processes, requires effective solutions to decrease the humanity's dependence on this type of fuels. Biomass feedstock (neutral carbon fuel), which includes energy crops and municipal, animal, and crops wastes, is a good renewable source for energy conversion via thermal processes such as full combustion and gasification. Combustion and gasification of biomass are processes that do not increase the carbon in the atmosphere since the carbon content in biomass has been previously taken from the ambient through the photosynthesis process. Due to the fact that biomass is considered a low heating value fuel, it is more appropriate for gasification than for direct combustion since combustion biomass can lead to combustion instability. Full combustion and air-biomass gasification have been deeply studied for a long time $[1,2]$. However, air-steam, oxygen-steam gasification, pyrolysis, and steam reforming gasification are new technologies recently studied, in order to improve the quality of syngas and liquid fuel produced. Colombia is the third coffee-producer around the world [3]. During 2015, Colombia produced 14.2 millions of green coffee (1 sack $=60 \mathrm{~kg}$.) sacks (the terminus green coffee or gold coffee is the name for coffee bean after it has been separated from its wrappers through the shelling process) [4]. Coffee husk $(\mathrm{CH})$ is a by-product from coffee seed shelling; for example, $100 \mathrm{~kg}$ of coffee seed produces about $86 \mathrm{~kg}$ of green coffee and $14 \mathrm{~kg}$ of $\mathrm{CH}$ [5], which leads to a production of about 138697 tons of $\mathrm{CH}$ per year in Colombia. In Colombia, many coffee agroindustries do not have the appropriate $\mathrm{CH}$, waste handling infrastructure, which could result in the pollution of natural sources [6]. Using $\mathrm{CH}$ wastes as feedstock for locally placed gasification can reduce both the pollution generated by coffee industries and the dependence of these industries on fossil fuels. 


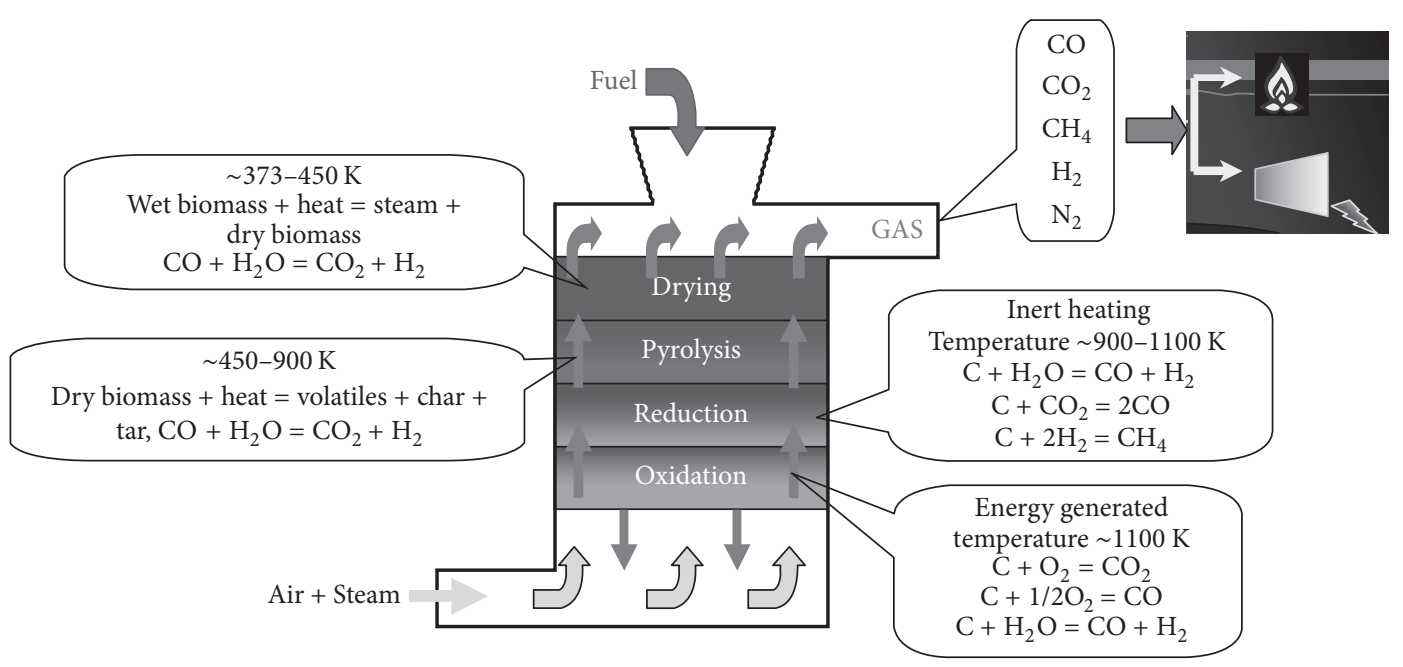

FIGURE 1: Stages and reactions in a fixed-bed gasifier, adopted from [17].

In an updraft fixed-bed gasifier, the biomass undergoes four stages, known as drying, pyrolysis, reduction, and oxidation [7]. Each of these stages occurs in a certain zone, as shown in Figure 1. The biomass enters at the top of the gasifier and goes down to the drying zone $(373 \mathrm{~K}<T<450 \mathrm{~K})$ where the moisture content is released [8]. Afterwards, the biomass descends to the pyrolysis zone $(450 \mathrm{~K}<T<900 \mathrm{~K})$ to release the Volatile Matter (VM) and to produce char, which descends to the reduction zone where the $\mathrm{C}$ atoms reacts with gases $\left(\mathrm{H}_{2} \mathrm{O}, \mathrm{CO}_{2}\right.$, and $\left.\mathrm{H}_{2}\right)$ coming from the combustion zone to produce secondary products such as $\mathrm{CO}, \mathrm{H}_{2}$, and $\mathrm{CH}_{4}$ [9]. The remaining char, from the reduction zone, passes to the combustion zone where the $\mathrm{C}$ atoms are oxidized with the oxygen from the air supplied to produce $\mathrm{CO}$ and $\mathrm{CO}_{2}$ and the heat required to drive the system. Also, in the combustion zone the $\mathrm{C}$ atoms from biomass react with the $\mathrm{H}_{2} \mathrm{O}$ supplied to produce $\mathrm{CO}$ and $\mathrm{H}_{2}$. Due to the fact that in a fixed-bed gasifier the different stages of biomass gasification occur in different zones, those gasifiers are the most appropriate to control some reactions and to produce certain desired species as required [10]. The oxidizer in gasification processes may be air [11], pure oxygen, pure steam [12], or blends of these [1316].

During biomass gasification, many parallel and competitive chemical reactions take place, making it a chemically complex process [19]. However, the global biomass gasification process can be reduced to a set of global reactions as shown in Table 1. Reaction enthalpies $\left(\Delta H_{\mathrm{r}}^{\theta}\right)$ lower than zero and higher than zero imply exothermic and endothermic reactions, respectively. Reactions $\left(R_{2}\right),\left(R_{3}\right)$, and $\left(R_{5}\right)$ are heterogeneous reactions occurring in the oxidation zone, whereas reactions $\left(R_{4}\right)$ and $\left(R_{6}\right)$ are typically heterogeneous reactions that occur in the reduction zone. Homogeneous reactions usually happen in the upper reactor zones. The species leaving the reactor depend on operating parameters such as temperature, pressure, species concentration, biomass particle size, and residence time [20]. The time for developing
TABLE 1: Chemical reactions in gasification process, adapted from $[9,21,22]$.

\begin{tabular}{lc}
\hline Chemical reaction & $\begin{array}{c}\Delta H_{\mathrm{r}}^{\theta} \\
{[\mathrm{kJ} / \mathrm{mol}]}\end{array}$ \\
\hline $\mathrm{R}_{1}:$ Solid Biomass $\rightarrow \mathrm{VM}+$ Char + Tar & \\
Char combustion & -111 \\
$\mathrm{R}_{2}: \mathrm{C}_{2}+(1 / 2) \mathrm{O}_{2} \rightarrow \mathrm{C}+\mathrm{CO}$ & -394 \\
$\mathrm{R}_{3}: \mathrm{C}+\mathrm{O}_{2} \rightarrow \mathrm{CO}_{2}$ & \\
Char gasification & 173 \\
$\mathrm{R}_{4}: \mathrm{C}+\mathrm{CO}_{2} \rightarrow 2 \mathrm{CO}$ & 131 \\
$\mathrm{R}_{5}: \mathrm{C}+\mathrm{H}_{2} \mathrm{O} \rightarrow \mathrm{CO}+\mathrm{H}_{2}$ & -75 \\
$\mathrm{R}_{6}: \mathrm{C}+2 \mathrm{H}_{2} \rightarrow \mathrm{CH}$ & \\
Homogeneous reactions & -283 \\
$\mathrm{R}_{7}: \mathrm{CO}+(1 / 2) \mathrm{O}_{2} \rightarrow \mathrm{CO}_{2}$ & -242 \\
$\mathrm{R}_{8}: \mathrm{H}_{2}+(1 / 2) \mathrm{O}_{2} \rightarrow \mathrm{H}_{2} \mathrm{O}$ & -803 \\
$\mathrm{R}_{9}: \mathrm{CH}+2 \mathrm{O}_{2} \rightarrow \mathrm{CO}_{2}+2 \mathrm{H}_{2} \mathrm{O}$ & -41 \\
$\mathrm{R}_{10}: \mathrm{CO}+\mathrm{H}_{2} \mathrm{O} \rightarrow \mathrm{CO}_{2}+\mathrm{H}_{2}$ & 206 \\
$\mathrm{R}_{11}: \mathrm{CH}_{4}+\mathrm{H}_{2} \mathrm{O} \rightarrow \mathrm{CO}^{2} 3 \mathrm{H}_{2}$ & \\
\hline
\end{tabular}

heterogeneous reactions is much longer than those for homogeneous reactions.

Air-blown gasification processes of wood and coal have been used during a long time to produce a syngas basically composed of $\mathrm{CH}_{4}, \mathrm{CO}_{2}, \mathrm{CO}, \mathrm{N}_{2}, \mathrm{H}_{2}$, and $\mathrm{H}_{2} \mathrm{O}$. Due to the necessity of improving syngas quality (gases rich in $\mathrm{H}_{2}$ ), other gasification processes, which use air-steam, oxygen-steam, and pure steam as oxidizing source in different gasifiers (fluidized-bed, cross draft, etc.), have been studied [23, 24]. Mostly, gasification using air or pure oxygen as oxidizing source produces a syngas with high $\mathrm{CO}$ and $\mathrm{CH}_{4}$ concentrations, whereas gasification with steam or mixtures of air or oxygen with steam results in a syngas rich in $\mathrm{H}_{2}$ [22, 25]. Typically, gasification using only steam (steam reforming) is 
an endothermic process that produces a mixture of $\mathrm{H}_{2}, \mathrm{CO}$, and $\mathrm{CO}_{2}[26]$.

In 2008, Gao et al. [12] performed a study on the hydrogen production using pine sawdust in a counter-current fixedbed gasifier. The parameters investigated were temperature, the steam-biomass $(\mathrm{S} / \mathrm{B})$ ratio, and equivalence ratio (ER $\left(\right.$ In [12] $\mathrm{ER}=\mathrm{Air}_{\text {actual }} / \mathrm{Air}_{\text {stoichiometric }}$.)). In this research, the tar generated in the gasification process was cracked using a porous ceramic reformer. Thus, hydrogen concentration was higher than that without using a porous ceramic reforming. In 2009, Gordillo and Annamalai [9] performed a study on dairy biomass adiabatic gasification carried out in a fixedbed gasifier and using air-steam blends as oxidizing source. The effects of ER and SF on syngas composition $\left(\mathrm{H}_{2}, \mathrm{CO}\right.$, $\mathrm{CO}_{2}, \mathrm{~N}_{2}, \mathrm{CH}_{4}$, and $\mathrm{C}_{2} \mathrm{H}_{6}$ ), temperature profiles, syngas $\mathrm{HHV}$, and energy conversion were discussed. In 2008, Plis and Wilk [13] discussed the gas yield in a $50 \mathrm{~kW} / \mathrm{hr}$ fixed-bed gasifier using air as oxidizer and wood pellets as fuel biomass. Parametric studies on the experimental performance, $(\lambda=$ $\mathrm{Air}_{\text {actual }} / \mathrm{Air}_{\text {stoichiometric }}$ ), and the biomass MC (moisture content) were developed. The syngas produced in this study was blended with coal to run a cocombustor. In 2009, Vélez et al. [14] carried out an experimental study on fluidizedbed cogasification of coal with biomass using a mixture of air-steam as oxidizing source. Blends of coal with $6 \%-15 \%$ of coffee husk $(\mathrm{CH})$, rice husk $(\mathrm{RH})$, and sawdust contents were used as feedstock. The parameters studied were Rac $\left(\mathrm{Rac}=\mathrm{kg}_{\text {air }} / \mathrm{kg}_{\text {fuel }}\right)$ and $\mathrm{Rvc}\left(\mathrm{Rvc}=\mathrm{kg}_{\text {steam }} / \mathrm{kg}_{\text {fuel }}\right)$ ranging from $2 \mathrm{~kg} / \mathrm{kg}$ to $3 \mathrm{~kg} / \mathrm{kg}$ and from $0.1 \mathrm{~kg} / \mathrm{kg}$ to $0.8 \mathrm{~kg} / \mathrm{kg}$, respectively. The effects of these parameters on syngas HHV were discussed. In 2010, Wilson et al. [15] gasified coffee husk using oxygen-nitrogen/steam blends at different gasification temperatures $\left(900^{\circ} \mathrm{C}, 800^{\circ} \mathrm{C}\right.$, and $\left.700^{\circ} \mathrm{C}\right)$, concluding that increasing temperature resulted in a linear increase in the $\mathrm{CO}$ content in syngas. At lower $\mathrm{O}_{2}$ concentrations, the above effect is more pronounced. When gasification temperature was increased from $700^{\circ} \mathrm{C}$ to $900^{\circ} \mathrm{C}$, the $\mathrm{CO}$ produced, at $2 \%$ of $\mathrm{O}_{2}$, was enhanced by 6 and 2.5 times in a pure $\mathrm{N}_{2}$ environment. In 2011, Gordillo and Rodriguez [27] published a modeling study on coffee gasification using air-steam as oxidizing source. The Chemical Equilibrium with Applications program (CEA), developed by NASA, was used to estimate the effect of equivalence ratio (ER) and steam to fuel (SF) ratio on equilibrium temperature and gas composition of $\sim$ 150 species. The results showed that increased ER and ( $\mathrm{S}: \mathrm{F})$ ratios produce mixtures that are rich in $\mathrm{H}_{2}$ and $\mathrm{CO}_{2}$ but poor in CO.

From the literature review, it is apparent that there are no preliminary experimental studies on Colombian coffee husk gasification using air-steam blends in a fixed-bed countercurrent gasifier. The current paper presents results obtained from an experimental air-steam fixed gasification study of coffee husk. The effects of operating parameters, such as equivalence ratio (ER) and steam to fuel (SF) ratio, on temperature profile along gasifier axis, syngas composition, syngas HHV, and energy recovery, are discussed. Typically, results obtained from this research were $\mathrm{HHV}_{\max }=$ $5085 \mathrm{~kJ} / \mathrm{m}^{3}$ and molar concentration (dry basis) $\mathrm{H}_{2}=19.07 \%$;
$\mathrm{CO}=13.49 \% ; \mathrm{CO}_{2}=21.78 \%$; and $\mathrm{CH}_{4}=4.1 \%$. These results are discussed and analyzed in the current paper.

Full or stoichiometric combustion occurs when it is used only the necessary amount of $\mathrm{O}_{2}$ for total oxidation of the atoms contained in the fuel (see (1)). This process (stoichiometric combustion) is basically used to produce heat.

$$
\mathrm{CH}_{h} \mathrm{O}_{o} \mathrm{~N}_{n} \mathrm{~S}_{s}+a \mathrm{O}_{2} \longrightarrow b \mathrm{CO}_{2}+c \mathrm{H}_{2} \mathrm{O}+d \mathrm{SO}_{2}+e \mathrm{~N}_{2} \text {. }
$$

On the other hand, partial oxidation or gasification (rich mixtures) uses lower oxygen than that required for theoretical combustion and produces a fuel gas known as syngas. According to the desired syngas composition, the gasification process must be carried out using different oxidizing sources such as pure air, pure oxygen, or pure steam. Also, mixtures of air or oxygen with steam are used. Equation (2) shows an air-steam biomass reaction producing only the most important species. The composition of syngas produced, under air-steam biomass gasification, typically, depends on some operating parameters such as equivalence ratio (ER, see (3)) and steam to fuel (SF, see (4)) ratio.

$$
\begin{aligned}
& \mathrm{CH}_{h} \mathrm{O}_{o} \mathrm{~N}_{n} \mathrm{~S}_{s}+f \mathrm{H}_{2} \mathrm{O}+g\left(\mathrm{O}_{2}+3,76 \mathrm{~N}_{2}\right) \\
& \quad \longrightarrow h \mathrm{CO}_{2}+i \mathrm{CO}+j \mathrm{CH}_{4}+l \mathrm{H}_{2} \mathrm{~S}+m \mathrm{~N}_{2}+n \mathrm{H}_{2} \\
& \mathrm{ER}=\frac{\text { stoichometric air moles }}{\text { actual air moles }}=\frac{a}{g} \\
& \mathrm{SF}=\frac{\text { actual steam moles }}{\text { actual fuel moles }}=f .
\end{aligned}
$$

\section{Material and Methods}

2.1. Experimental Facility. Figure 2 shows a diagram of the experimental facility used in the study. The facility consists of (i) a biomass hopper where biomass is stored; (ii) a $102 \mathrm{~cm}$ tall small-scale $(10 \mathrm{~kW} / \mathrm{hr}$.) updraft fixed-bed gasifier, built of castable alumina refractory tube (inner and outer diameter of $127 \mathrm{~mm}$ (5 in) and $25.4 \mathrm{~cm}$ (10 in), resp.), surrounded by $5.08 \mathrm{~cm}$ fiberglass insulating blanket layer in order to reduce heat lost; (iii) a steam generator built of a $10 \mathrm{~cm}$ internal diameter stainless steel tube, surrounded by a heating tape element, with variable power output $(350-1000 \mathrm{~W})$ to control vapor flow rate generation from $1.27 \mathrm{~g} / \mathrm{min}$ to $17.25 \mathrm{~g} / \mathrm{min}$; (iv) an ash collector system consisting of a conical vibrating grate and an ash deposit placed under the grate. The conical grate (drilled with several holes) was built of cast iron and attached to a pneumatic vibrator to maintain continuous ash removal and hence quasi-steady-state operating conditions; (v) a cleaning and drying system, composed of filters and condensers to clean and dry, respectively, the syngas samples; condenser was cooled using cold water at $0^{\circ} \mathrm{C}$; (vi) a temperature recorder system to record every minute the temperature measured by eight K-type thermocouples placed at 8 different points through the bed; (vii) a gas analyzer system where the syngas, previously cleaned, is analyzed; this gas analyzer analyzes and records mole fraction of $\mathrm{CO}, \mathrm{CH}_{4}, \mathrm{H}_{2}, \mathrm{CO}$, $\mathrm{CO}_{2}$, and $\mathrm{C}_{n} \mathrm{H}_{m}$; and (viii) a combustion chamber to burn the syngas leaving both the gasifier and the gas analyzer. 


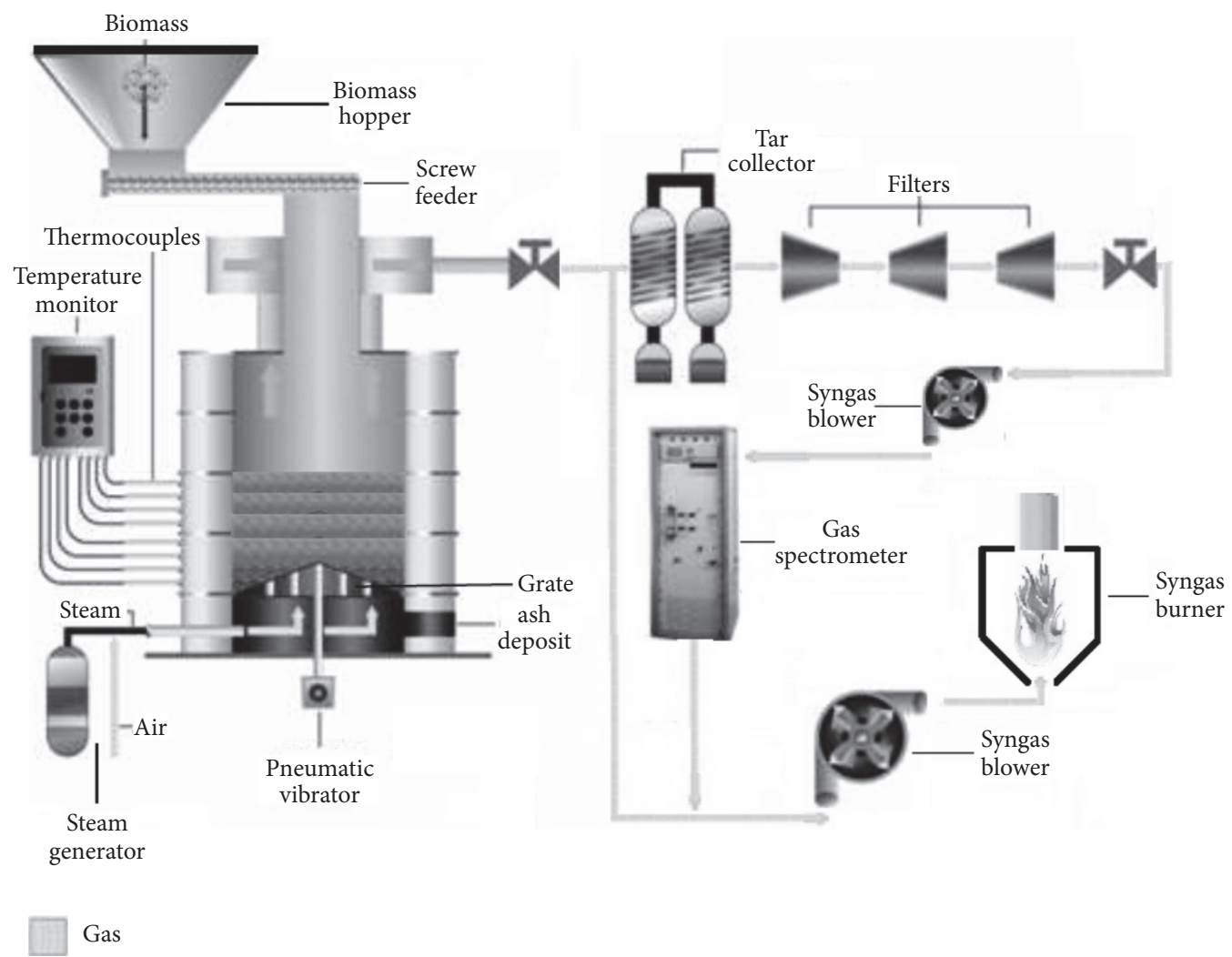

FIGURE 2: Schematic gasification facility, adapted from [18].

TABLE 2: Experimental parameters.

\begin{tabular}{|c|c|}
\hline Air pressure and temperature. & 0.76 bar, $92^{\circ} \mathrm{C}$ \\
\hline Bed height. & $180 \mathrm{~mm}$ \\
\hline Fuel biomass. & Coffee husk \\
\hline Particle size. & Flake where $80 \%$ of mass is $d_{p}<4 \mathrm{~mm}$ \\
\hline Biomass flow rate. & $0.166 \mathrm{~g} / \mathrm{s}(600 \mathrm{~g} / \mathrm{h})$ \\
\hline Air flow. & $\begin{array}{c}17.3 \text { SFCH-69.2 SFCH } \\
\left(0.49 \mathrm{SATP} \mathrm{m}^{3} / \mathrm{h}-1.96 \mathrm{SATP} \mathrm{m}^{3} / \mathrm{h}\right)\end{array}$ \\
\hline Steam flow. & $\begin{array}{c}1.32 \mathrm{~g} / \mathrm{min}-5.16 \mathrm{~g} / \mathrm{min} \\
(79.2 \mathrm{~g} / \mathrm{h}-309.6 \mathrm{~g} / \mathrm{h})\end{array}$ \\
\hline ER & $1.53-6.11$ \\
\hline SF & $0.23-0.87$ \\
\hline
\end{tabular}

2.2. Operating Conditions and Procedure. The experimental procedure was performed according to the parameters shown in Table 2.

Every experiment started with preheating the gasifier using a propane torch just located under the grate. When the temperature, $2 \mathrm{~cm}$ above the grate, was about $550^{\circ} \mathrm{C}$ (about 25 minutes after having turned on the torch), the torch was turned off and the screw feeder started to supply biomass to the gasifier until the bed height was about $18 \mathrm{~cm}$. Then, the air and steam started to be supplied to the gasifier at flow rates as required to maintain the desired experimental operating parameters (ER and SF) shown in Table 2. At this time, the temperature started to be measured and stored using the temperature data logger. As biomass was gasified the bed height decreased and ash accumulated on the grate. Then, biomass was added every 10 minutes and in batches as required. Also, ash was continuously removed from the top of the grate to the gasifier plenum through the vibrating grate, whose vibrating frequency was adjusted to maintain a constant $2 \mathrm{~cm}$ - thickness ash layer. When the gasification system stabilized, that is, peak temperature, measuring $2 \mathrm{~cm}$ above of the grate, started to be constant, without changing its position, the gas samples, taken from the top of the gasifier at a rate of $1 \mathrm{~L} / \mathrm{min}$, were cleaned and dried to analyze their composition $\left(\mathrm{CO}_{2}, \mathrm{CO}, \mathrm{CH}_{4}, \mathrm{C}_{2} \mathrm{H}_{6}, \mathrm{H}_{2}, \mathrm{O}_{2}\right.$, and $\left.\mathrm{N}_{2}\right)$, at real time and during 10 minutes, by the gas analyzer whose 
ranges are $\mathrm{CO}_{2}$ between 0 and $40 \%$, $\mathrm{CO}$ between 0 and $30 \%$, $\mathrm{CH}_{4}$ between 0 and $10 \%, \mathrm{H}_{2}$ between 0 and $40 \%$, and $\mathrm{C}_{2} \mathrm{H}_{6}$ between 0 and $5 \%$. For all experiments, the biomass flow rate was maintained constant at $600 \mathrm{~g} / \mathrm{h}$ while the flows rates of air and steam were adjusted at the values given in Table 2 in order to maintain the desired operating (ER and SF) conditions. For all experiments, the air and steam were supplied to the gasifier at $75 \mathrm{kPa}$ and temperatures of $20^{\circ} \mathrm{C}$ and $92^{\circ} \mathrm{C}$, respectively, The temperatures along the gasifier bed were measured by ktype thermocouples placed at 2, 4, 6, 8, 10,12, 14, and $16 \mathrm{~cm}$ above the cast iron grate and recorded, at real time, every minute by the temperature recorder.

\section{Results and Discussion}

3.1. Uncertainty Analysis. The uncertainty at measurements of temperature, air flow, fuel flow, and syngas compound were found by the following equations that calculate the total uncertainty and uncertainty propagation, respectively.

$$
\begin{aligned}
& \sigma_{x_{i}}^{2}=B_{x_{i}}^{2}+P_{x_{i}}^{2}, \\
& \sigma_{r}^{2}=\sum_{i=1}^{j}\left(\frac{\partial r}{\partial x_{i}}\right)^{2} \sigma_{x_{i}}^{2},
\end{aligned}
$$

where $r=r\left(x_{1}, x_{2}, \ldots, x_{2}\right)$ is function of $x_{i}$ measured variables of $j, \sigma_{r}, \sigma_{x_{i}}$ are uncertainties of $r$ and $x_{i}$, respectively, and $B_{x_{i}}$ and $P_{x_{i}}$ are systematic uncertainties and random uncertainties of $x_{i}$. The temperatures in the gasifier bed were measured by k-type thermocouples with a $\pm 0.75 \%$ accuracy in the range of measured temperatures. The uncertainty derived from thermocouple operation was taken to $\pm 0.15 \%$. Then, the total uncertainty of temperature is $\pm 0.76 \%$ by (5). The air flow was measured by a rotameter with $100 \mathrm{SFCH}$ full scale $\left(2.83 \mathrm{~m}^{3} / \mathrm{h}\right)$ and resolution of $5 \mathrm{SFCH}\left(0.14 \mathrm{~m}^{3} / \mathrm{h}\right)$ and accuracy of $\pm 4 \%$; the total uncertainty of air flow is $\pm 4 \%$ by (5). A rotameter with $9.96 \mathrm{~cm}^{3} / \mathrm{min}$ full scale and $0.066 \mathrm{~cm}^{3} / \mathrm{min}$ resolution was used to measure the water flow to the gasifier. This rotameter has an accuracy of $\pm 1 \%$. Thus, total uncertainty to water flow is $\pm 1 \%$. The feeding system (screw feeder) was calibrated previously and its systematic uncertainty was $\pm 3.42 \%$. The total uncertainty of scale used to measure the sample weight was $\pm 1 \%$, whereas the total uncertainty of the timer used to measure the feed rate was $\pm 3.87 \%$. The uncertainties of ER and SF are functions of two variables, which were calculated by using (6), resulting in $\pm 5.57 \%$ for ER and $\pm 4.12 \%$ for the SF ratio. The total uncertainty to every syngas compound is function of $\pm 1 \%$ accuracy only. Table 3 summarizes total uncertainties.

3.2. Fuel Characterization. $\mathrm{CH}$ samples were obtained from the Colombian coffee agroindustry and were characterized by ultimate and proximate analyses. Table 4 shows results from these analyses along with the empirical formula that was derived using atom balance on compounds. Also, mesh size particle of samples was determined and results are shown in Table 5.
TABLE 3: Uncertainty of gasification parameters.

\begin{tabular}{lc}
\hline Variable & Uncertainty $\%$ \\
\hline Temperature & $\pm 0.76 \%$ \\
Air flow & $\pm 4.00 \%$ \\
Steam flow & $\pm 1.00 \%$ \\
Feed rate & $\pm 3.87 \%$ \\
ER & $\pm 5.57 \%$ \\
SF & $\pm 4.12 \%$ \\
MS compounds & $\pm 1.00 \%$ \\
\hline
\end{tabular}

TABle 4: Proximate and ultimate analysis of $\mathrm{CH}$.

\begin{tabular}{lc}
\hline Moisture \% & 10,10 \\
Volatiles \% & 79,86 \\
Ash \% & 1,20 \\
FC \% & 8,84 \\
C \% & 44,52 \\
H \% & 6,03 \\
N \% & 0,78 \\
O \% & 48,38 \\
S \% & 0,29 \\
HHV (kJ/kg) & 18740 \\
DRY HHV (kJ/kg) & 20845 \\
DAF HHV (kJ/kg) & 21127 \\
Empirical formula & $\mathrm{CH}_{1,63} \mathrm{~N}_{0,015} \mathrm{O}_{0,82} \mathrm{~S}_{0,0024}$ \\
\hline
\end{tabular}

TABLE 5: Mesh particle size characterization of $\mathrm{CH}$.

\begin{tabular}{lc}
\hline Particle size $[\mathrm{mm}]$ & Mass percentage of the samples \\
\hline$[6.7 ; \infty)$ & 0.02 \\
{$[5.6 ; 6.7)$} & 0.08 \\
{$[4.0 ; 5.6)$} & 2.33 \\
{$[2.8 ; 4.0)$} & 19.33 \\
{$[2.0 ; 2.8)$} & 20.60 \\
{$[1.7 ; 2.0)$} & 9.94 \\
{$[1.0 ; 1.7)$} & 20.54 \\
{$[0.5 ; 1.0)$} & 14.01 \\
{$[0.0 ; 0.5)$} & 13,15 \\
\hline
\end{tabular}

3.3. Temperature Profiles. Figures 3-8 show results on temperature profile along the gasifier axis for different ER and SF ratios. Although experimentation was carried out at 1.53 $<\mathrm{ER}<6.11$, temperature profiles are shown only for ER of $1.53,3.07,4.09$, and 6.11 . Temperature data is given at quasi-steady-state conditions. Full steady state conditions were impossible to achieve due to batch biomass supply. The tendency of the curves shows that increasing ER tends to decrease temperatures due to less air supplied to the gasifier. This leads to decreased char oxidation rate, because char oxidation is diffusion controlled; hence its rate depends on the oxygen available in the combustion zone. Lower char oxidation rates result in lower temperatures, since char oxidation (heterogeneous reactions 3 and 4) is an exothermic process that releases the heat required for the global gasification. The temperatures peaks, shown in the curves trend from 


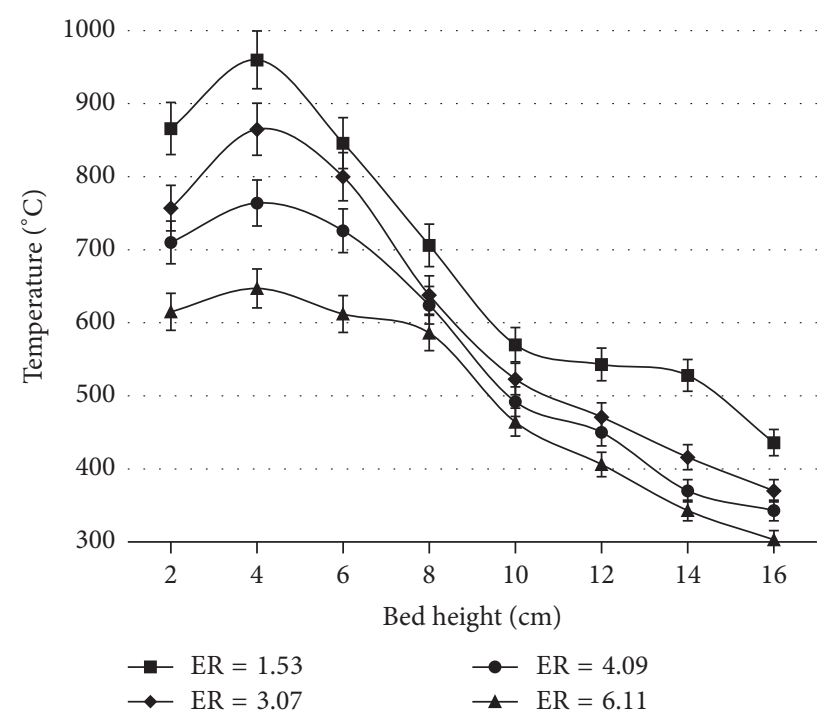

FIgURE 3: Temperature profile along with gasifier axis at $\mathrm{SF}=0$.

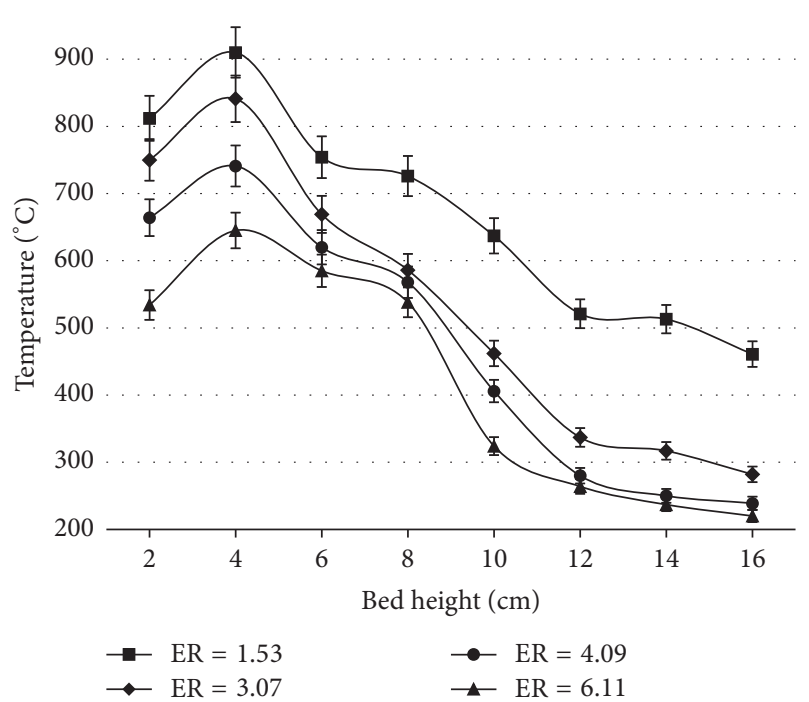

FIGURE 4: Temperature profile along with gasifier axis at $\mathrm{SF}=0.23$.

Figures 3-8, show the place where the char oxidation occurs. For almost all experimentation cases the char oxidation occurred $4 \mathrm{~cm}$ above the grate, indicating that quasi-steadystate was achieved. When fixed gasification is carried out under unsteady operating conditions the maximum temperature in the combustion zone move up through the gasifier axis due to ash accumulation on the grate. In the current experimentation the ash was removed to the gasifier plenum by a vibrating grate.

It is apparent from these results that increased SF ratios also decrease peak temperatures (Figure 8). Increased SF implies more steam supplied to the gasifier; hence the reaction of char in the combustion zone takes place under reach-steam conditions, which implies more of the char reacting with the steam through the endothermic reaction $\mathrm{R}_{5}$ to produce $\mathrm{H}_{2}$ and $\mathrm{CO}$. The maximum peak temperature

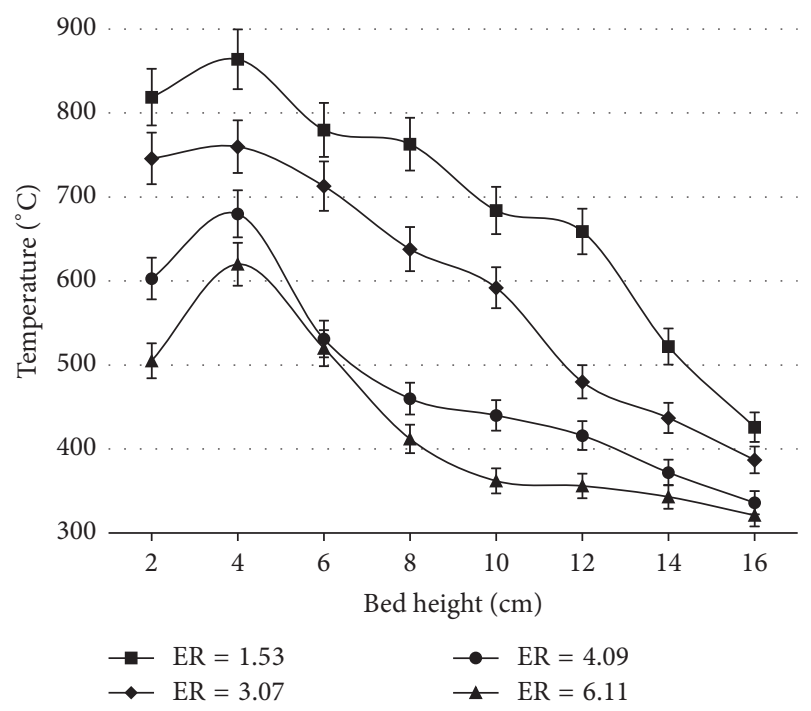

FIgURE 5: Temperature profile along with gasifier axis at $\mathrm{SF}=0.38$.

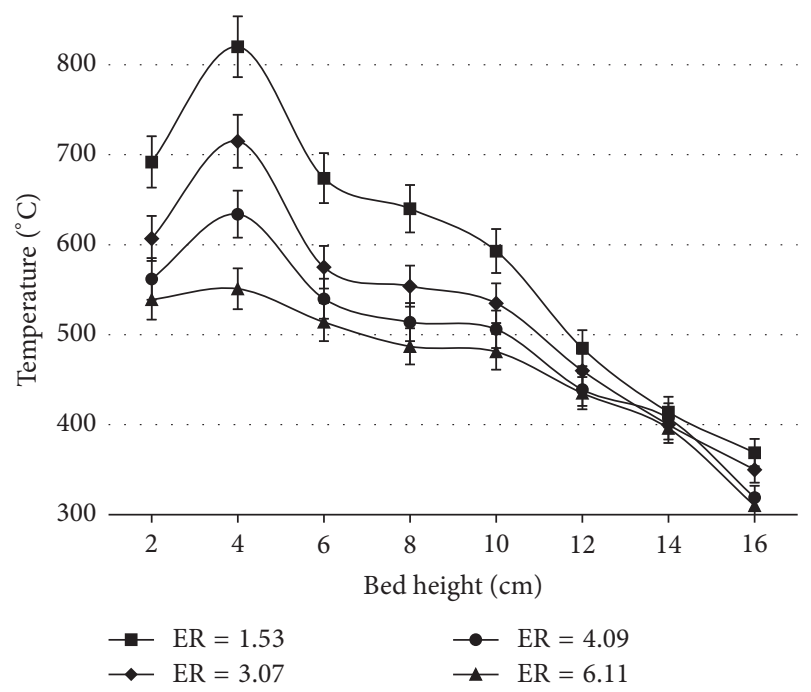

Figure 6: Temperature profile along with gasifier axis at $\mathrm{SF}=0.59$.

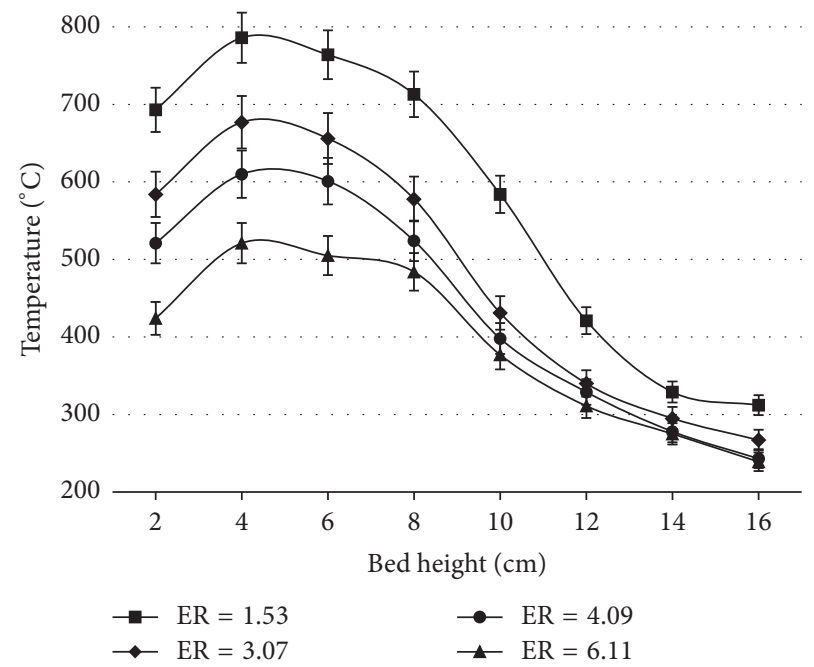

Figure 7: Temperature profile along with gasifier axis at $\mathrm{SF}=0.87$. 


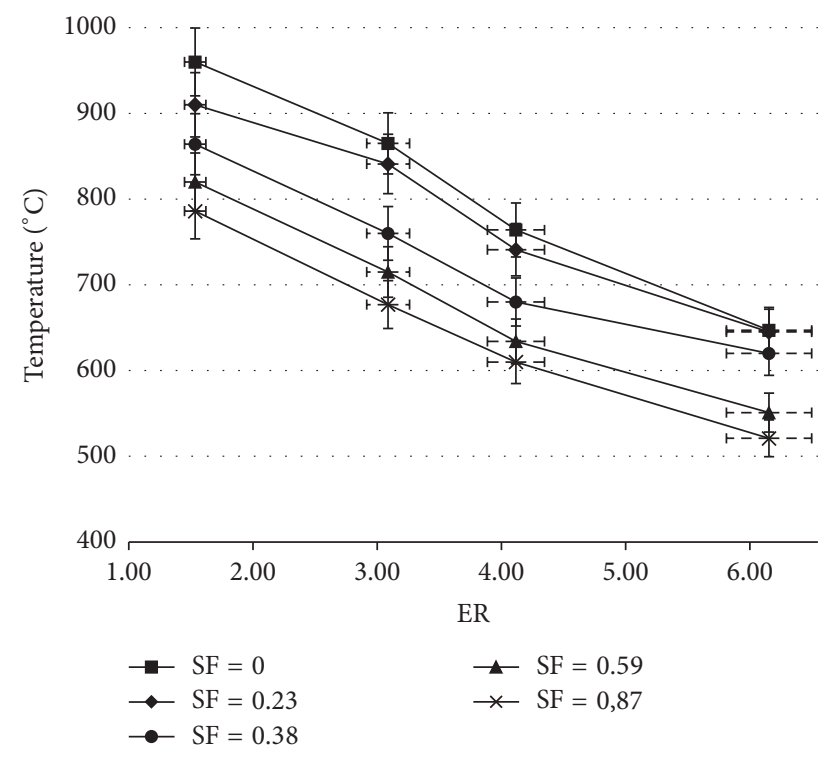

FIGURE 8: Temperature peaks versus ER for several SFs.

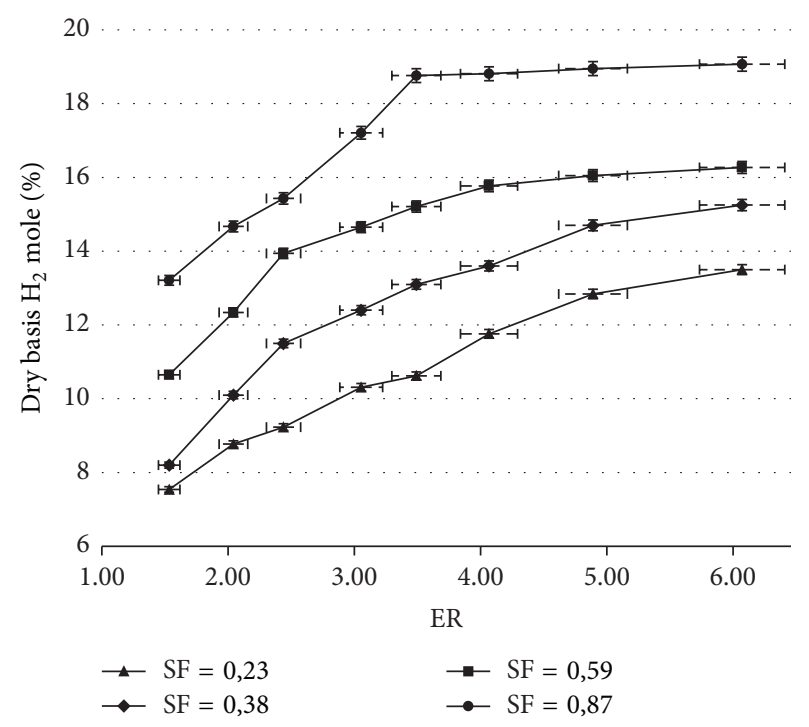

FIGURE 9: $\mathrm{H}_{2}$ production versus ER for several SFs.

$\left(960^{\circ} \mathrm{C}\right)$ was reached for air-gasification $(\mathrm{SF}=0)$ due to no $\mathrm{H}_{2} \mathrm{O}$ in the combustion zone.

Also, results from temperature profile show that temperatures at $2 \mathrm{~cm}$ above the grate are lower than these at the combustion zone (peak temperature), indicating that at this point ( $2 \mathrm{~cm}$ above the grate) there is ash accumulation. On the other hand, the temperature, above the combustion zone ( $4 \mathrm{~cm}$ up to the grate), decreases since the reactions occurring at these zones (reduction, pyrolysis, and drying) are endothermic.

3.4. Gas Composition. In this section (Figures 9-11), the results on syngas composition are presented for only relevant species in a dry tar free basis. Species in trace amount are not

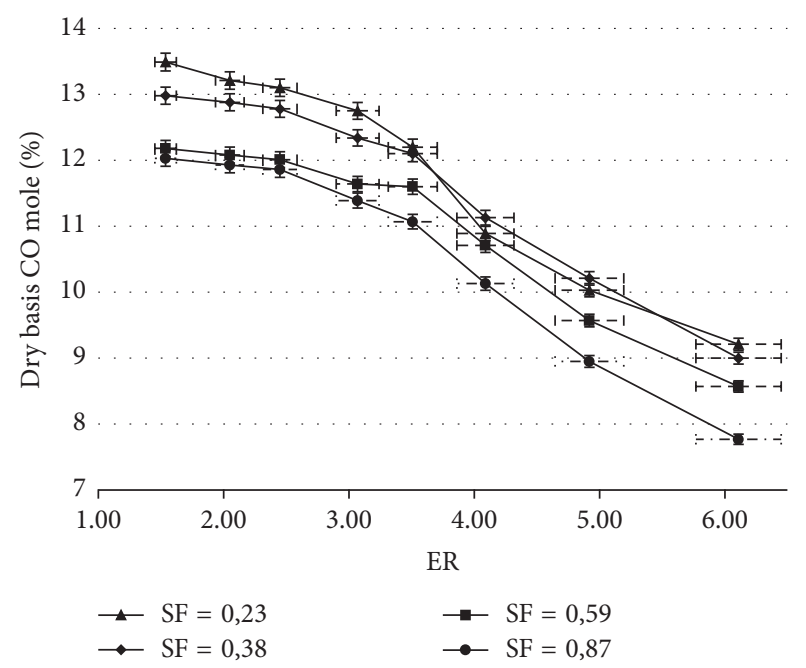

FIGURE 10: CO concentration at several SFs versus ER.

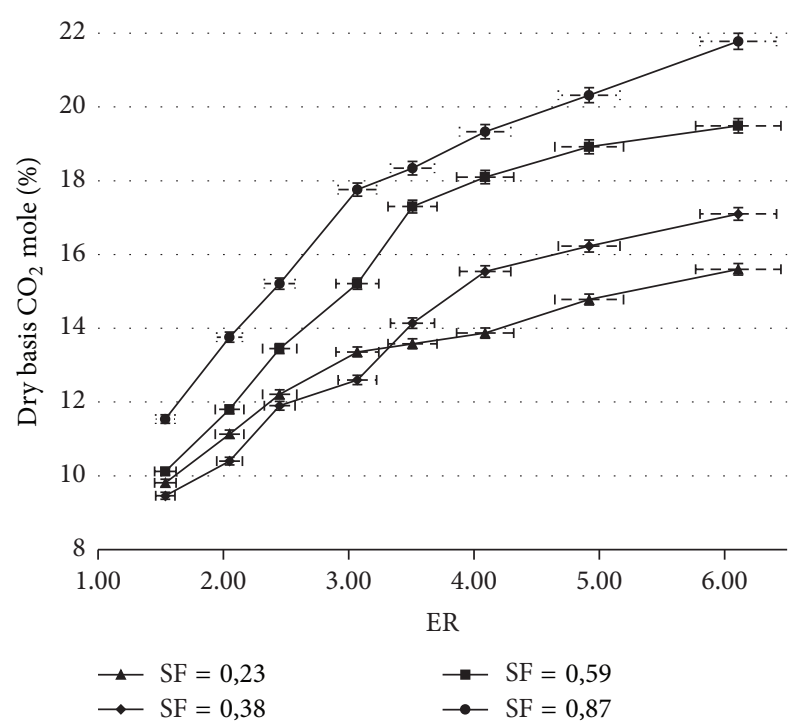

FIGURE 11: $\mathrm{CO}_{2}$ concentration at several SFs versus ER.

shown. Figure 9 illustrates the $\mathrm{H}_{2}$ content in syngas as a function of ER for several SFs. It is apparent that $\mathrm{H}_{2}$ production increases when both ER and SF are increased. Increasing SF, at constant ER, leads to an $\mathrm{H}_{2} \mathrm{O}$-rich combustion environment, so those reactions $\left(R_{5}\right.$ and $\left.R_{10}\right)$, which produce $H_{2}$, are favored. That is, steam reforming reaction (reaction $\mathrm{R}_{5}$ ), which produces $\mathrm{H}_{2}$ and $\mathrm{CO}$ through the reaction of $\mathrm{C}$ atoms with $\mathrm{H}_{2} \mathrm{O}$, takes place in the combustion and reduction zones ( $4 \mathrm{~cm}$ above the grade) where all water vapor supplied with the air is available. Thus, the char reaction occurs in an $\mathrm{H}_{2} \mathrm{O}$-rich mixture. which increases the reaction rate of char, resulting in high productions of $\mathrm{H}_{2}$ and $\mathrm{CO}$. However, Figure 10 shows a decreased production of $\mathrm{CO}$ while SF increases, which suggest that much of the $\mathrm{CO}$ produced by the steam reforming reaction $\left(R_{5}\right)$ in the combustion and reduction zones is consumed by the shift reaction $\left(R_{10}\right)$ in the 
upper zones (pyrolysis and drying) to produce more $\mathrm{H}_{2}$ and $\mathrm{CO}_{2}$.

In general, results show that $\mathrm{H}_{2}$ increases and $\mathrm{CO}$ decreases with increased ER. At constant SF, increasing ER implies less $\mathrm{O}_{2}$ supplied to the gasifier, resulting in $\mathrm{H}_{2} \mathrm{O}$-rich mixtures that are favorable for the reaction of char with $\mathrm{H}_{2} \mathrm{O}$ (reforming reaction) to produce $\mathrm{H}_{2}$ and CO. Also, higher ER leads to lower combustion temperatures (peak temperatures), which are more appropriate for the production of $\mathrm{CO}_{2}$ than $\mathrm{CO}$, via char oxidation (reaction $\mathrm{R}_{3}$ ). Oxidation of char to produce $\mathrm{CO}$ and $\mathrm{CO}_{2}$ via reactions $\mathrm{R}_{2}$ and $\mathrm{R}_{3}$ is competitive, and their reaction rates are very dependent on the temperature; low temperatures favor the production of $\mathrm{CO}_{2}$ through reaction $\mathrm{R}_{3}$ [9]. Less production of $\mathrm{CO}$ implies more $\mathrm{O}_{2}$ free to react with remaining char and hence more $\mathrm{CO}_{2}$ (Figure 11).

From Figure 9, it is apparent that the variation of ER is more important on the $\mathrm{H}_{2}$ production at lower SF ratios than at higher $\mathrm{SF}$ : at $\mathrm{SF}=0.23$, increasing the $\mathrm{ER}$ from 1.53 to 6.11 increases the $\mathrm{H}_{2}$ production by $79 \%$, whereas at $\mathrm{SF}=0.87$, the same increase (1.53 to 6.11) in the ER only rises the $\mathrm{H}_{2}$ production by $44.3 \%$. On the other hand, at $\mathrm{ER}=1.53$, increasing SF from 0.23 to 0.87 increases the $\mathrm{H}_{2}$ concentration by $75.2 \%$, but, at $\mathrm{ER}=6.11$, the same increase in $\mathrm{SF}(0.23$ to 0.87$)$ only increases the $\mathrm{H}_{2}$ production by $41.2 \%$. This suggests that the influence of SF on the $\mathrm{H}_{2}$ production is more important at lower ER than at higher ER.

For all SF, the slopes of CO-curves are higher at ER > 3.51 than those at ER $\leq 3.5$ (Figure 10). In other words, for any increase in ER the decrease in CO is higher at ER > 3.51 than at $\mathrm{ER}<3.51$ (i.e., at $\mathrm{SF}=0.87$, increasing $\mathrm{ER}$ from 1.54 to 3.51 decreases $\mathrm{CO}$ by about $8 \%$ while increasing ER from 3.51 to 6.11 decreases CO by about $30 \%$ ). The effect of increased ER on the decrease of temperature peak (combustion zone) is higher at ER $>3.51$ than that at ER $<3.51$ (Figure 8). Thus, increasing ER decreases more the production of $\mathrm{CO}$, via reaction $\mathrm{R}_{2}$, at $E R>3.51$ than at $E R<3.51$. Also, it is apparent that $\mathrm{R}_{3}$ (oxidation of char to produce $\mathrm{CO}_{2}$ ) is more important at $\mathrm{ER}>3.51$ than at $\mathrm{ER}<3.51$.

Figure 12 shows $\mathrm{CH}_{4}$ production as a function of ER for different SF. Increasing both ER and SF increases $\mathrm{H}_{2}$ production (Figure 9). Thus, the production of $\mathrm{CH}_{4}$, via the heterogeneous reaction $\mathrm{R}_{6}$, is favored (Figure 12) due to higher $\mathrm{H}_{2}$ concentration in the reduction zone. The maximum $\mathrm{CH}_{4}$ was about $4.1 \%$, which indicates that most of the $\mathrm{CH}_{4}$ produced in the reduction zone, via reaction $\mathrm{R}_{6}$, is consumed by the reforming of $\mathrm{CH}_{4}\left(\mathrm{R}_{11}\right)$ above of the reduction zone.

3.5. HHV of Syngas and Energy Conversion Efficiency. The syngas higher heating values (HHV), calculated by (7), are presented in Table 6 as a function of ER and SF.

$$
\mathrm{HHV}_{\text {syngas }}=\sum_{i=1}^{j} X_{i} \cdot \mathrm{HHV}_{i} \text {, }
$$

where $X_{i}$ and $\mathrm{HHV}_{i}$ are the molar fraction and higher heating value of each gas fuel, contained in syngas, respectively.

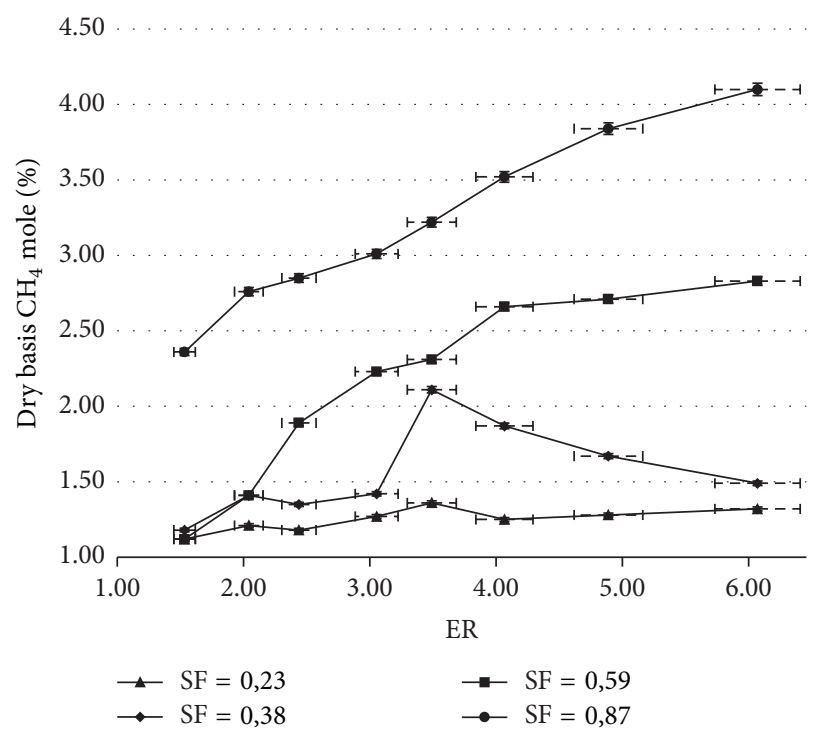

FIGURE 12: $\mathrm{CH}_{4}$ concentration at several SFs versus ER.

TABLE 6: Dry basis syngas HHV [kJ/SATP $\mathrm{m}^{3}$ ] for several SF and ER ratios.

\begin{tabular}{lllllllll}
\hline \multirow{2}{*}{ SF } & \multicolumn{8}{c}{ ER } \\
& 1.53 & 2.05 & 2.45 & 3.07 & 3.51 & 4.09 & 4.92 & 6.11 \\
\hline 0.23 & 3112 & 3130 & 3075 & 3216 & 3248 & 3300 & 3386 & 3413 \\
0.38 & 3132 & 3478 & 3622 & 3710 & 4042 & 3887 & 3832 & 3678 \\
0.59 & 3445 & 3764 & 4147 & 4318 & 4391 & 4464 & 4376 & 4312 \\
0.87 & 4148 & 4482 & 4604 & 4836 & 5077 & 5085 & 5081 & 5052 \\
\hline
\end{tabular}

$\mathrm{HHV}_{\text {syngas }}$ is the high heating value $\left(\mathrm{kJ} / \mathrm{SATP} \mathrm{m}^{3}\right.$ of dry syngas).

Table 6 presents results on $\mathrm{HHV}_{\text {syngas }}$ for different ER and $\mathrm{SF}$. At $\mathrm{SF}=0.23$ increased ER increases $\mathrm{HHV}_{\text {syngas }}$. However, at $\mathrm{SF} \geq 0.38$, the $\mathrm{HHV}_{\text {syngas }}$ presents a maximum value at $\mathrm{ER}=3.51$ or $\mathrm{ER}=4.09$. In general, $\mathrm{HHV}_{\text {syngas }}$ increases with a higher $\mathrm{ER}$, because the syngas has more $\mathrm{CH}_{4}$ content $\left(\mathrm{HHV}_{\mathrm{CH} 4}=36339 \mathrm{~kJ} / \mathrm{SATP} \mathrm{m}^{3}\right.$ of $\left.\mathrm{CH}_{4}\right)$. According to the results, the $\mathrm{H}_{2}$ content in syngas is inversely proportional to the $\mathrm{CO}$ content; more $\mathrm{H}_{2}$ implies less $\mathrm{CO}$. This suggests that the $\mathrm{HHV}_{\text {syngas }}$ increases with increased ER, mainly, due to more production of $\mathrm{CH}_{4}$, since the energy density of $\mathrm{CO}$ $\left(11567 \mathrm{~kJ} / \mathrm{SATP} \mathrm{m}^{3}\right.$ of CO) is very similar to that of the $\mathrm{H}_{2}$ $\left(11600 \mathrm{~kJ} / \mathrm{SATP} \mathrm{m}^{3}\right.$ of $\left.\mathrm{H}_{2}\right)$.

Although $\mathrm{HHV}_{\text {syngas }}$ gives information on syngas energy density, it does not give information on energy recovered in syngas for each biomass unit gasified. The energy recovery (dry tar free basis) was estimated using the following:

$$
\begin{aligned}
& \eta_{\text {Gas }, E} \\
& =\frac{\mathrm{HHV}_{\text {syngas }}}{N_{\text {Fuel }} * \mathrm{HHV}_{\text {Fuel }}+N_{\text {steam }} * 18\left(h_{v}+4.18(365-293)\right)},
\end{aligned}
$$

where $\mathrm{HHV}_{\text {syngas }}$ is the higher heating value of syngas on a dry basis, $N_{\text {Fuel }}$ and $N_{\text {steam }}$ are the moles of biomass and steam supplied to the gasifier, respectively, by each normal $\mathrm{m}^{3}$ of dry 
TABLE 7: Dry tar free energy recovery for several ER and SFs.

\begin{tabular}{lllllllll}
\hline \multirow{2}{*}{ SF } & \multicolumn{7}{c}{ ER } \\
& 1.53 & 2.05 & 2.45 & 3.07 & 3.51 & 4.09 & 4.92 & 6.11 \\
\hline 0.23 & 0.44 & 0.36 & 0.31 & 0.26 & 0.23 & 0.19 & 0.17 & 0.14 \\
0.38 & 0.44 & 0.38 & 0.34 & 0.29 & 0.28 & 0.24 & 0.2 & 0.15 \\
0.59 & 0.47 & 0.41 & 0.40 & 0.35 & 0.32 & 0.29 & 0.24 & 0.19 \\
0.87 & 0.62 & 0.53 & 0.48 & 0.43 & 0.41 & 0.36 & 0.30 & 0.24 \\
\hline
\end{tabular}

syngas produced, $\mathrm{HHV}_{\text {Fuel }}$ corresponds to the gross heating value of DAF fuel $\left(\mathrm{kJ} / \mathrm{m}^{3}\right)$, and $h_{v}$ is the vaporization enthalpy of water $\left(\mathrm{kJ} / \mathrm{kg} \_\right.$K.). Since it was impossible to measure flows rates of both tar and water in the syngas, the syngas flow rate, required to estimate energy recovery, was estimated using atom balance on reactants (biomass, air, and steam) and products (tar composition, char, water in syngas, and dry syngas composition). Table 7 presents dry tar free energy recovery, which refers to energy recovered in syngas for each unit biomass gasified. The remaining energy is in tar, char, and energy lost by radiation and convection on the outside walls of the reactor.

From the results presented in Table 7, it can be concluded that increased ER tends to reduce energy recovery, whereas energy recovery increases with a higher SF. In general, the energy recovery ranged between $14 \%$ and $62 \%$; the remaining percentage of energy is in tar, char, and latent heat of syngas.

\section{Conclusions}

(i) The temperature in the combustion zone ranged from $521^{\circ} \mathrm{C}$ to $960^{\circ} \mathrm{C}$. Lower values of peak temperature are because of higher SFs, which favor the endothermic char reforming reaction $\left(\mathrm{C}+\mathrm{H}_{2} \mathrm{O} \rightarrow \mathrm{CO}+\mathrm{H}_{2}\right)$. Above the combustion zone ( $4 \mathrm{~cm}$ up to the grate), temperature decreases because of the presence of endothermic reactions in the reduction, pyrolysis, and drying zones, with the exception of the shift reaction $\left(\mathrm{CO}+\mathrm{H}_{2} \mathrm{O} \rightarrow \mathrm{CO}_{2}+\mathrm{H}_{2}\right)$.

(ii) Increasing both $\mathrm{ER}$ and $\mathrm{SF}$ produces mixtures rich in $\mathrm{H}_{2}, \mathrm{CH}_{4}$, and $\mathrm{CO}_{2}$, but poor in $\mathrm{CO}$, due to the fact that $\mathrm{H}_{2}$ and $\mathrm{CO}_{2}$ are competitive species with $\mathrm{CO}$, via the shift reaction $\left(\mathrm{CO}+\mathrm{H}_{2} \mathrm{O} \rightarrow \mathrm{CO}_{2}+\mathrm{H}_{2}\right)$. Also, $\mathrm{CO}$ and $\mathrm{CO}_{2}$, produced by char oxidation via reactions $\mathrm{C}_{2}+(1 / 2) \mathrm{O}_{2} \rightarrow \mathrm{C}+\mathrm{CO}$ and $\mathrm{C}+\mathrm{O}_{2} \rightarrow \mathrm{CO}_{2}$, are competitive. $\mathrm{H}_{2}$ content in the syngas ranged from $7.54 \%$ to $19.07 \%$, whereas CO content in syngas was from 7.77 to $13.49 \%$. On the other hand, the maximum $\mathrm{CH} 4$ content was of $4.10 \%$.

(iii) HHV of syngas varied from $3112 \mathrm{~kJ} / \mathrm{SATP} \mathrm{m}^{3}$ to $5085 \mathrm{~kJ} / \mathrm{SATP} \mathrm{m}^{3}$. Those values are similar to the ones reported in previous gasification studies. That is, high heating values (HHV), ranging from $3268 \mathrm{~kJ} / \mathrm{SATP} \mathrm{m}^{3}$ to $4581 \mathrm{~kJ} / \mathrm{SATP} \mathrm{m}^{3}$, were reported by [9] Gordillo and Annamalai, for a syngas obtained from air-steam dairy biomass gasification. (iv) The quality of syngas produced highly depends on operating parameters such as ER and SF. If rich$\mathrm{H}_{2}$ syngas mixtures are desired, gasification must be carried out under higher ER and SF ratios.

(v) Air-steam gasification of coffee husk is possible without heat addition under $1.54<\mathrm{ER}<6.11$ and $0.23<$ $\mathrm{SF}<0.87$. At $\mathrm{ER}>6.11$ and $\mathrm{SF}>0.87$, gasification of $\mathrm{CH}$ tends to be near global pyrolysis, since at these conditions the temperature at the combustion zone is only $521^{\circ} \mathrm{C}$, which is not much higher than the ignition temperature of $\mathrm{C}\left(400^{\circ} \mathrm{C}\right)$.

\section{Additional Points}

Highlights. (i) Biomass gasification for treatment of agroindustrial wastes is used. (ii) Syngas is generated through an updraft gasifier using coffee husk as fuel. (iii) Syngas HHV based on both air and steam as gasifying agents is improved.

\section{Conflicts of Interest}

The authors declare that they have no conflicts of interest.

\section{Acknowledgments}

The financial support from the internal financing grants of the Andes University and ECCI University is gratefully acknowledged.

\section{References}

[1] A. Williams, J. M. Jones, L. Ma, and M. Pourkashanian, "Pollutants from the combustion of solid biomass fuels," Progress in Energy and Combustion Science, vol. 38, no. 2, pp. 113-137, 2012.

[2] R. Saidur, E. Abdelaziz, A. Demirbas, M. Hossain, and S. Mekhilef, "A review on biomass as a fuel for boilers," Renewable and Sustainable Energy Reviews, vol. 15, no. 5, pp. 2262-2289, 2011.

[3] International Coffee Organization, International Coffee Organization, Enero 2016, http://www.ico.org/trade_statistics.asp.

[4] Federacion Nacional de Cafeteros de Colombia, Federación Nacional de Cafeteros de Colombia, enero 2016, http://www .federaciondecafeteros.org/particulares/es/quienes_somos/119_ estadisticas_historicas/.

[5] Institute of Nutrition of Central America and Panama, PULPA DE CAFÉ: composición, tecnología y utilización, Bogotá: CIID, 1978.

[6] J. L. De Oliveira, J. N. Da Silva, E. Graciosa Pereira, D. Oliveira Filho, and D. Rizzo Carvalho, "Characterization and mapping of waste from coffee and eucalyptus production in Brazil for thermochemical conversion of energy via gasification," Renewable and Sustainable Energy Reviews, vol. 21, pp. 52-58, 2013.

[7] S. Priyadarsan, K. Annamalai, J. M. Sweeten, S. Mukhtar, and M. T. Holtzapple, "Fixed-bed gasification of feedlot manuere and poultry litter biomass," Transactions of the ASAE, vol. 47, no. 5, pp. 1689-1696, 2004.

[8] P. Basu, "Gasification Theory," in Biomass Gasification, Pyrolysis and Torrefaction, pp. 199-248, Academic Press, 2ed edition, 2013. 
[9] G. Gordillo and K. Annamalai, "Adiabatic fixed bed gasification of dairy biomass with air and steam," Fuel, vol. 89, no. 2, pp. 384-391, 2009.

[10] P. Basu, "Design of Biomass Gasifiers," in Biomass Gasification and Pyrolysis, pp. 167-228, Academic Press, 2010.

[11] G. Gordillo, K. Annamalai, and N. Carlin, "Adiabatic fixed-bed gasification of coal, dairy biomass, and feedlot biomass using an air-steam mixture as an oxidizing agent," Renewable Energy, vol. 34, no. 12, pp. 2789-2797, 2009.

[12] N. Gao, A. Li, C. Quan, and F. Gao, "Hydrogen-rich gas production from biomass steam gasification in an updraft fixedbed gasifier combined with a porous ceramic reformer," International Journal of Hydrogen Energy, vol. 33, no. 20, pp. 5430-5438, 2008.

[13] P. Plis and R. K. Wilk, "Theoretical and experimental investigation of biomass gasification process in a fixed bed gasifier," Energy, vol. 36, no. 6, pp. 3838-3845, 2008.

[14] J. F. Vélez, F. Chejne, C. F. Valdés, E. J. Emery, and C. A. Londoño, "Co-gasification of Colombian coal and biomass in fluidized bed: an experimental study," Fuel, vol. 88, no. 3, pp. 424-430, 2009.

[15] L. Wilson, G. R. John, C. F. Mhilu, W. Yang, and W. Blasiak, "Coffee husks gasification using high temperature air/steam agent," Fuel Processing Technology, vol. 91, no. 10, pp. 1330-1337, 2010.

[16] S. Sun, Y. Zhao, F. Ling, and F. Su, "Experimental research on air staged cyclone gasification of rice husk," Fuel Processing Technology, vol. 90, no. 4, pp. 465-471, 2009.

[17] G. Gordillo, Fixed bed counter-current low temperature gasification of dairy biomass and coal-daiy biomass blends usin air-steam as oxidizer [PhD dissertation], Texas A\&M University, 2009.

[18] J. Bonilla, Estudio del efecto de relación equivalencia y la relación vapor combustible en la producción de gases combustibles por gasificación del cisco de café usando mezclas de aire-vapor para extracción parcial [MSc Disseratation], Universidad de los Andes, 2012.

[19] K. Zhang, J. Chang, Y. Guan, H. Chen, Y. Yang, and J. Jiang, "Lignocellulosic biomass gasification technology in China," Renewable Energy, vol. 49, pp. 175-184, 2013.

[20] C. A. Ibrahim Dincer, "Green methods for hydrogen production," International Journal of Hydrogen, vol. 40, no. 34, pp. 11094-11111, 2012.

[21] A. Gómez-Barea and B. Leckner, "Modeling of biomass gasification in fluidized bed," Progress in Energy and Combustion Science, vol. 36, no. 4, pp. 444-509, 2010.

[22] P. Parthasarathy and K. S. Narayanan, "Hydrogen production from steam gasification of biomass: Influence of process parameters on hydrogen yield - A review," Renewable Energy, vol. 66, pp. 570-579, 2014.

[23] H. L. Chum and R. P. Overend, "Biomass and renewable fuels," Fuel Processing Technology, vol. 71, no. 1-3, pp. 187-195, 2001.

[24] S. S. Thanapal, K. Annamalai, J. M. Sweeten, and G. Gordillo, "Fixed bed gasification of dairy biomass with enriched air mixture," Applied Energy, vol. 97, pp. 525-531, 2012.

[25] S. Sharma and P. N. Sheth, "Air-steam biomass gasification: Experiments, modeling and simulation," Energy Conversion and Management, vol. 110, pp. 307-318, 2016.

[26] E. Balu, U. Lee, and J. N. Chung, "High temperature steam gasification of woody biomass - A combined experimental and mathematical modeling approach," International Journal of Hydrogen Energy, vol. 40, no. 41, pp. 14104-14115, 2015.
[27] G. Gordillo and C. Rodriguez, "Adiabatic gasification and pyrolysis of coffee husk using air-steam for partial oxidation," Journal of Combustion, vol. 2011, Article ID 303168, 2011. 


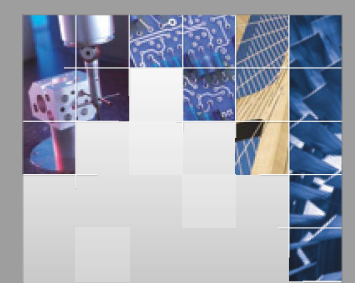

\section{Enfincering}
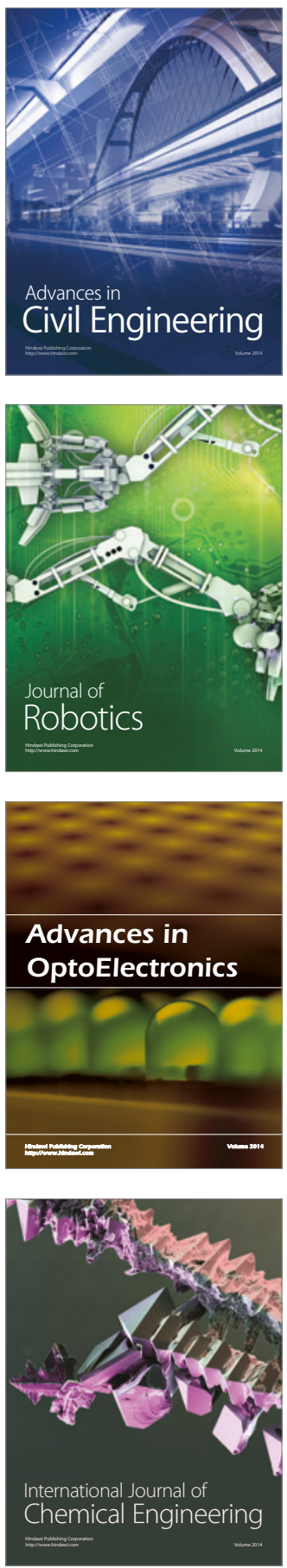

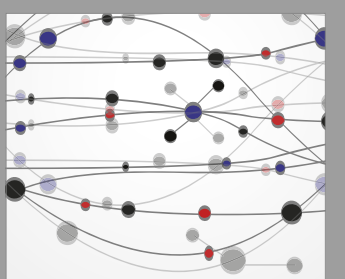

The Scientific World Journal

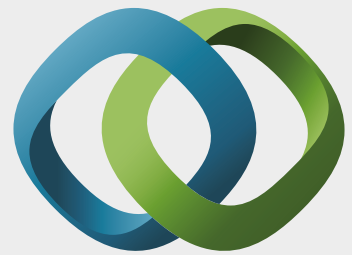

\section{Hindawi}

Submit your manuscripts at

https://www.hindawi.com
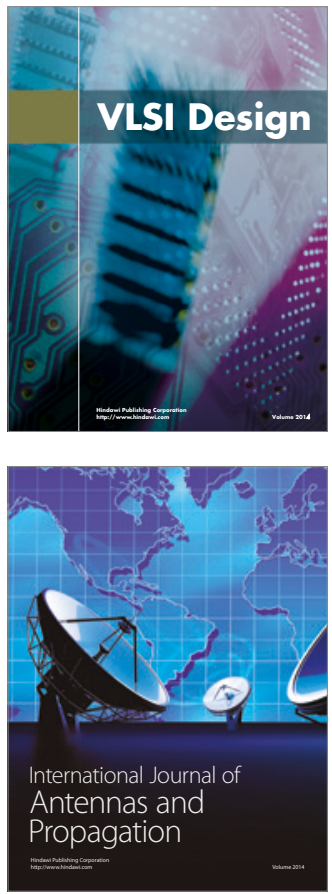

\section{Rotating}

Machinery
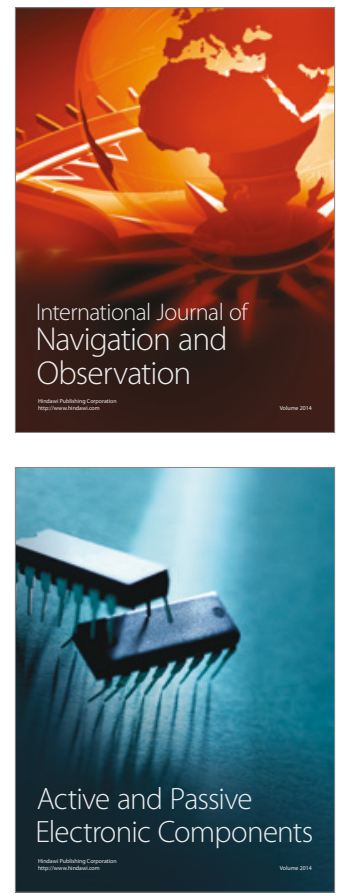
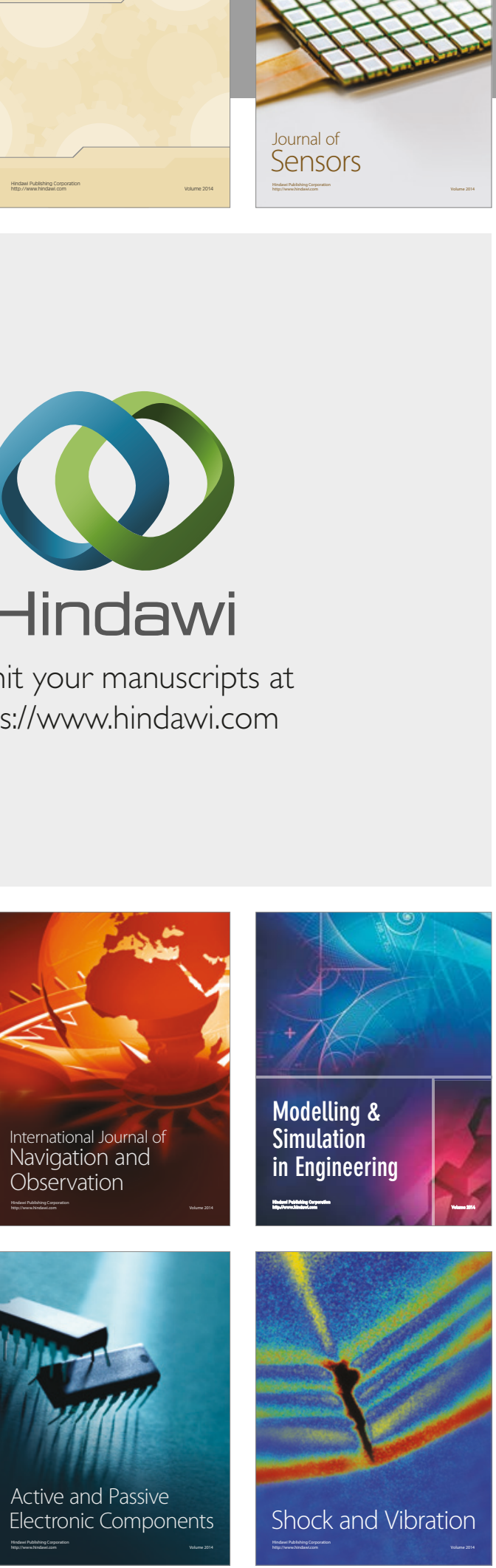
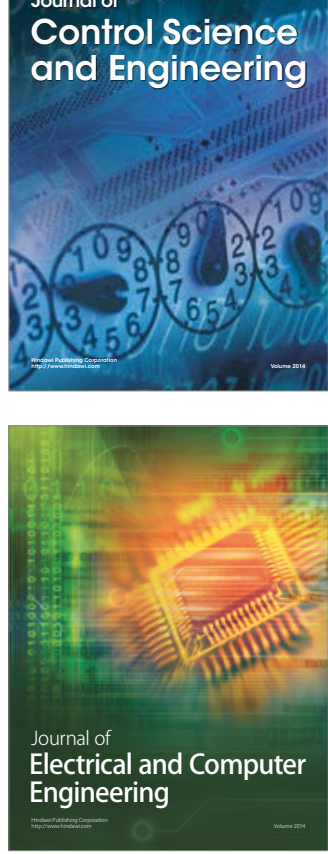

Distributed

Journal of

Control Science

and Engineering
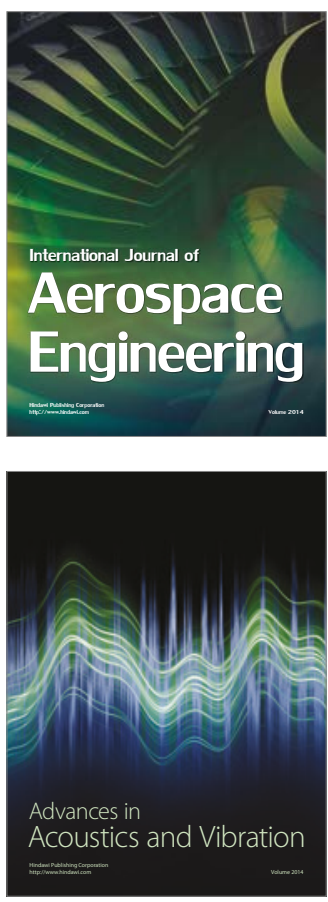

Sensor Networks 